\title{
Psycho-immune Partnership in the Dynamic Responses of Living Systems
}

\author{
Suhovey Yu. G. ${ }^{1}$, Koptyug A. V. ${ }^{* 2}$, Petrov S. A. ${ }^{3}$, Dotsenko E. L. ${ }^{4}$, Fisher T. A. ${ }^{5}$ \\ ${ }^{1}$ Scientitic Research Institute of Clinical Immunology, Siberian Branch of Russian Academy of Medical Sciences, Melinkajte \\ st. 89A-119, 625027, Tyumen, Russia \\ ${ }^{2}$ Mid Sweden University, Department of Quality Technology, Management, Mechanical Engineering and Mathematics, \\ Akademigatan1, 83125, Östersund, Sweden \\ ${ }^{3}$ The Tyumen Centre of Sciences, Siberian Branch of Russian Academy of Sciences, Malygina st. 86, 625026, Tyumen, Russia \\ ${ }^{4}$ The Tyumen State University, Department of General and Social Psychology, 625003, Proezd 9 Maja, 5, Tyumen, Russia \\ ${ }^{5}$ The Tyumen Centre of Sciences, Siberian Branch of Russian Academy of Sciences, Malygina st. 86, 625026, Tyumen, Russia \\ 1i_yura62@mail.ru; ${ }^{* 2}$ andrei.koptioug@miun.se; ${ }^{3}$ tumiki@mail.ru; ${ }^{4}$ dotsenko_e@bk.ru; ${ }^{5}$ Fitan72@ mail.ru
}

\begin{abstract}
Present paper outlines certain possibilities for a new approach to the generalized modeling of the dynamics of living organism reaction to the changes in its environment. It is shown that there exists common functional "alignment" of the immune and psychic responses in the living organism reaction to the changes in the environment. This is manifested in the experimentally recorded matching of the response scenarios and activities in the immune and psychic domains. Thus, one may conclude that there exist two functionally matched systems (psychic and immune) tracking the external influences and responding to them. On the other hand it is feasible that one is actually dealing with a complex inseparable psycho-immune system and experimentally monitors different aspects of its activity describing these from two different points of view. Given analysis of available experimental data seems to support both of the above alternatives without giving undoubted preferences to any of them. However treating the situation form the formal logic point of view certain preferences can be given to the concept of an inseparable psycho-immune system modeled in two different ways. This approach can also resolve certain collisions happening with the attempts to describe direct interrelations between psychic and immune domains, and can lead the way to higher-level functionality models of the dynamic responses of the living organisms.
\end{abstract}

Keywords- Psychology; Immunity; Living Organism; Dynamic Responses to Stimuli; Complex System Modeling; Analysis; Experiment

\section{INTRODUCTION}

The idea on certain degree of relation between the psychic and immune systems is not new [1], but discussing relations between these two domains is extremely complex. Such discussions often leave specialists both in psychology and immunity deeply unsatisfied. According to the formal definitions psychology studies the dynamics of the living object interaction with the environment (its behavior) [2,3] and immunology studies the reactions of the living object to the presence of foreign structures [4-6]. But from the generalized point of view the overall subject of studies is exactly the same, namely the dynamics of the complex living object (organism) and its responses to external stimuli (environment, foreign influences, threats). Complex models were constructed to study, describe and forecast such dynamics (here the term model is used in a generalized way) with their specific approaches, simplifications to the object made to acquire clearer understanding, meta-language used (terminology) etc. Within the context of present paper only two knowledge areas out of many, where such generalized models are used, would be discussed, namely the psychological and immunological domains and corresponding model classes. Moreover, comparison of the models from these two classes should be done properly, using terms and statements more general than the ones taken from within each of these classes. It can be done, for example basing upon the generalized theory of modeling [7-10].

Two of the selected model classes were initially constructed with different goals in mind. They were developing quite independently for a long time, and essentially formed separate areas of knowledge (scientific disciplines). Thus, it is not surprising that these models use different descriptive meta-languages (including terminology) and different level of generalization or idealization (macro- and micro-levels of description). By the way of construction each and every model is intrinsically limited, as it should at the start present a simplified picture of the subject under study, just adequate for achieving its goals and providing the possibilities for the better system understanding [9, 10]. Both classes of models today are quite developed, were continuously improved and complimented and are successfully used (also for the prognostic purpose, which is one of the main reasons of constructing models [11, 12]). During the initial process of a complex living system simplification each of the mentioned classes outlined certain functional sub-system as a particular subject. And these functionally separated subsystems are generally called psychic and immune systems correspondingly.

It is worth mentioning here that even with complex inanimate systems (for example mechanical or electronic) a single 
construction element can often perform multiple functions, and thus with different approaches to the subsystem separation some parts can be attributed simultaneously to different sub-systems. So some of the selected subsystems in such case would not be independent, but will be intersecting and have one or few common elements. And if this is true for the inanimate systems which are generally easier to model than animate ones, it would be very hard to guarantee that psychology and immunology domains deal with separate and non-intersecting functional subsystems.

Thus, it seems that a significant amount of problems arising within attempts of comparison of the psychic and immune systems can be attributed to misunderstanding. In many cases it is forgotten that we are not comparing the functional subsystems (we have not even proven specifically that such separable subsystems do exist, and if so that they do not intersect). And instead we compare the models belonging to very different classes, very often also using the terms and meta-languages belonging to these classes. The same time there is a body of experimental evidence pointing to a certain "parallelism" or "synchronization" of the psychic and immune responses (e.g. responses of the system "living organism" studied from the points of view of two different disciplines) to similar (or identical) environmental changes, again and again raising the questions about the relations between the immunology and psychology domains.

In present paper we propose the formal logic- based approach to treating the interrelations between the psychic and immune domains, and outline possible ways of constructing new classes of generalized models, combining the advantages of existing psychological and immunological classes for studying and describing the dynamics of the reactions of the system "living organism" to the changes in its environment. Within this approach few hypotheses are put forward and analyzed basing on existing experimental data.

\section{HYPOTHESES}

With the existence of experimental facts that could be interpreted as pointing out to the similarities in two supposedly different domains within the complex system, which are also described by two different sets of dynamic models, one can hypothesize and put forward few possibilities for the interrelations formulated below as the hypotheses (A)-(D). These possibilities are directly related to the possible relations between two classes of functional models and, possibly, of two functional subsystems of the system under study (living organism).

\section{A. Formal Description of the Hypotheses}

Two selected model classes related to psychic and immune domains are constructed basing upon, and are designed to describe and forecast two classes of experimental phenomena happening in the complex living system as a dynamic reaction on dynamic changes in the system environment. Very often these phenomena are represented only by indirect reflections, and one mainly deals with certain outcomes $\mathbf{a}_{\mathbf{i}}$ and $\mathbf{b}_{\mathbf{i}}$ happening as the reaction of the living organism to the same or very similar changes in its environment (Fig. 1). We are trying to hypothesize on the possibilities as there is a certain likeness in the experimental outcomes in response to similar or identical stimuli.

\section{B. Coincidence Hypothesis (Random Coincidence)}

Two selected model classes are describing not coupled subsystems of the main system, namely the psychic system and immune system (subsystems A and B in Fig. 1A) really existing or functionally separable within the whole system under study.

Thus the likeness ("alignment", "parallelism") of the responses suggested by the experimental data is just a coincidence, creating the illusion that the subsystems A and B are somehow coupled. But in the reality there is no coupling, and the subsystems A and B are independent.

In this hypothesis the psychic and immune systems are functionally separable and not coupled at all (are independent).

\section{Parallelism Hypothesis (Parallelism, Synchronization)}

Two selected model classes are describing not coupled subsystems of the main system, namely the psychic system and immune system (subsystems A and B in Fig. 1B) really existing or functionally separable within the whole system under study. These subsystems are not coupled directly. But there exists a hierarchically superior subsystem $\mathrm{C}$ that in response to the changes in the environment causes the synchronized responses in the subsystems A and B, showing up as the response parallelism indicated by the experimental data.

In this hypothesis the psychic and immune systems are functionally separable and not coupled directly, but are interdependent via the third (unspecified) system.

\section{Coupling Hypothesis (Coupling)}

Two selected model classes are describing coupled subsystems of the main system, namely the psychic system and immune system (subsystems A and B in Fig. 1C) really existing or functionally separable within the whole system under study. Mutual coupling between subsystems A and B can have both "feedforward" (A -> B) and "feedback" (B -> A) loops. Such coupling also could contain multiple loops (possibly involving other subsystems- $\mathrm{C}$ in Fig. 1c), and be either linear or nonlinear and also 
have quite different coupling coefficients in the loops. External stimulation can directly affect one of the subsystems (A) causing it to respond; and the response in other subsystem (B) is initiated through the coupling causing experimentally recorded response parallelism.

In this hypothesis the psychic and immune systems are functionally separable and coupled. And the immune processes do influence psychic ones and vice versa, though different processes happen in two different subsystems. In a particular case one can suppose that the coupling is unidirectional, for example immune system influences psychic one, but not the other way around.
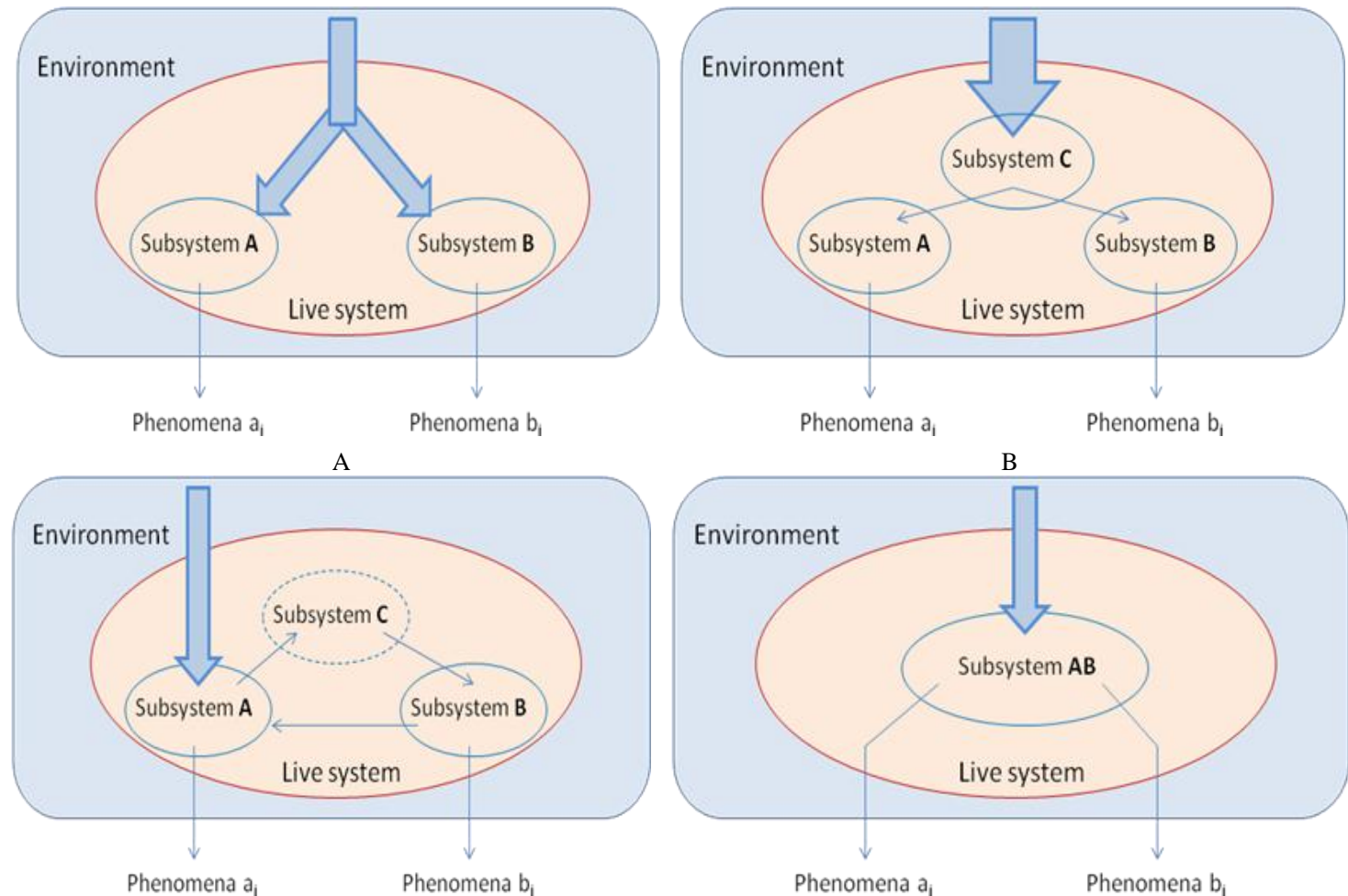

$\mathrm{C}$

$\mathrm{D}$

Fig. 1 Schematic illustration to the formulated hypotheses A-C correspondingly, see text for details

\section{E. Integration Hypothesis (Integrity)}

Two selected model classes are describing the dynamics of one and the same meta-system (or its subsystem AB, Fig. 1d), but do it from different points of view and using different meta-languages.

In this hypothesis it is not explicitly correct to talk about the psychic and immune systems, as these in a sense are just different descriptions of what happens within unified meta-system (the same features, the same processes, the same phenomena, but different points of view). And separating two subsystems basing on the functionality may not be possible or may never present a "clear cut".

\section{GENERAL DISCUSSION ON THE HYPOTHESES}

Hypotheses formulated above are quite generalized, and thus should be analyzed using corresponding general methodology. In order to avoid the meta-languages specific to one or another class of models (psychic or immune) we will use higher level abstractions and speak of the recognized phenomena in the dynamics of the living system as a whole, happening in reaction to the changes of its environment (external stimuli), and of the specifics of these two model classes constructed to describe such dynamics. With this approach it does not matter if the recognition of the functional subsystems within the main system is done, for example, only for the sake of better understanding. Analysis of the known experimental results will be carried out to assess the validity of the formulated hypotheses, and the probability that any of the formulated hypotheses is valid or invalid. We will also use more general term "domain" instead of more limiting "subsystem" (psychic and immune domains, instead of psychic and immune systems or subsystems).

It is interesting to start from the discussion of the collisions often happening with the attempts to "directly relate the psychic and immune systems". From the generalized analysis point of view formulated above the attempts of direct comparison, or direct interrelating of psychic and immune domains are plainly invalid. First of all in many such discussions the model descriptions are confused with the functional subsystems. Moreover, from the generalized point of view, huge success of 
two different classes of models describing the dynamics of essentially inseparable and very complex living system does not at all guarantee that these models describe two in reality separable subsystems (as it is not proven explicitly to be so). Two classes of the models were also constructed with very different purposes in mind. Thus in many cases the "contradictions" or "similarities" generated by such attempts of direct comparison, even with the attempts of putting into exact correspondence the terms and constructions of two different meta-languages used for different classes of models, are imaginary. Instead one can set up questions about the relation of the phenomena (classes of experimentally observed phenomena) described by two classes of models: are these classes of phenomena related? And if so, what are these relations? Or, maybe these phenomena are essentially the same (we just detect different "reflections", "manifestations") and we just study different aspects of the dynamics of the same system (see formulation of the hypotheses above)?

It follows from the accepted generalized approach to modeling that the way forward towards improving both of the classes of the particular models may be in constructing a new more general class, combining the strongest features of both. Such attempt can be successful if new problems that neither of the existing model classes can tackle separately would essentially demand such new models, and thus the purposes for new modeling approach are clearly formulated. There is a feeling that generating such new class of models is already a necessity.

It also follows from the generalized approach that certain differences in the discussed two model classes are already "built into them" at the earliest stages of their construction. One of the first stages in the model construction is the simplification of information about the original complex system (reduction) [9-12]. At this stage only the "major" parameters, facts, patterns that are most relevant for the specified modeling purposes are taken into account, and all the rest is neglected (and may or may not be taken into account at later stages of the model development). Thus different initial choices made already at the earliest stages very much define the model class originating from these initial models.

\section{ANALYSIS OF THE HYPOTHESES BASING ON THE AVAILABLE EXPERIMENTAL DATA}

One of the major conclusions of the few papers attempting to relate psychic and immune domains is in possible existence of certain coupling or connection between these two domains. But most often no discussion on the type of such coupling is given. The variety of experimental facts gathered up to date support the idea that the coupling between the psychic and immune domains (or, as it is commonly put, between the psychic and immune systems) may be actually quite tight. The change in the CD4+ and CD8+ T-lymphocyte numbers caused by the intense physical activities, relaxation, different types of physiological and psychological stress is experimentally proven for the animals and humans [13-16]. Suppression of the immune response is experimentally observed for mice with depression-like state induced in the inter-male confrontations [17], and in clearly depressive humans [18]. Immune reaction stimulation is observed for the aggressive animals (agnostic type behavior), and immune reaction suppression is observed for the submissive animals (submissive type behavior) [17, 19, 20]. There are experimentally observed differences in the interleukins IL1 and IL2 secretion related to the different aspects of social stress (cohabitation, dyadic collisions) [21]. It was also determined that changes in the immune response were dependent not only upon stress duration [22] and intensity [23] but also on the presence of psychological discomfort caused by the infantilism of the psychological defense mechanisms [24-26]. There is also well supported opinion on the convergence of the mechanisms of chronic stress, depression and neuroplasticity down to cellular and molecular levels [27].

So basing on the experimental data one can say that psychological and immune responses are working towards common goal, supporting the dynamic homeostasis [28-30], or more correctly the homeorhesis [31] (e.g. a special type of dynamic equilibrium), needed for the stable functioning of the living organism. The same time visible presence of common targets (tasks) for the processes happening in the immune and psychological domains may point to certain functional connection, or may be to some overlapping of these domains, to certain "partnerships" between the immune and psychological responses, or certain correlation between the processes in these two domains showing up as the correlation in the scenarios and in the ways of solving correlated tasks [32].

Taking into account specifics of the immune system some authors suggest that one can define it as a certain reflective (quasi- sensory) organ of the living organism formed in the course of evolution and used for the detection and response to chemical stimuli that are not directly detected by the neural system [27, 33]. Treating the immune domain in such way one can say that we include into it certain complex interlinked mechanisms realized on the system, cellular and molecular levels, which together provide a multi-level defense. On the other hand, psychological domain relates to the subjective reflection of the objective reality (through the processing of sensory signals and perceptively constructed images) regulating the functioning of the living organism, and operating at the higher level of system responses. 


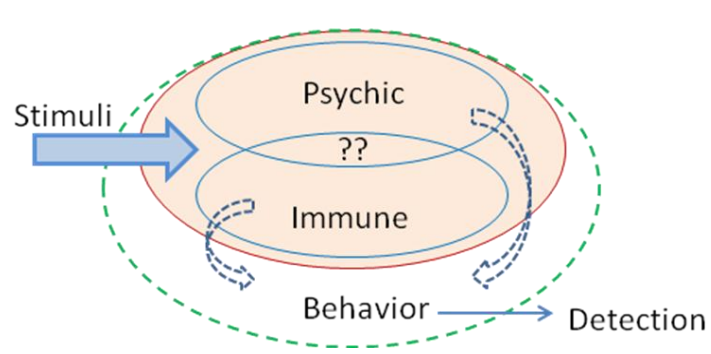

A

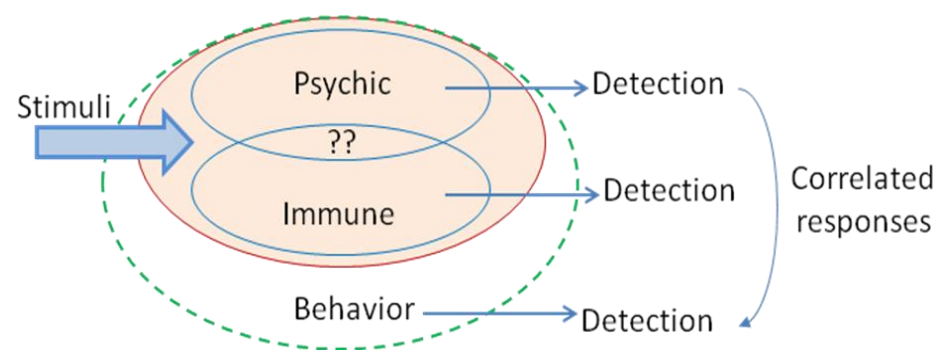

B

Fig. 2 Schematic illustration to the correlation of the detected responses, see text for details

So, basing on the available experimental data (including the facts described above) responses to the changes in the live system environment can be clearly detected in the behavioral patterns (Fig. 2A). And also the responses in the psychic and immune domain, correlated to each other and to the behavioral patterns can be detected as a reaction to the environmental changes (Fig. 2B). So the coincidence hypotheses $(\boldsymbol{A})$ seems the least probable of all suggested. Additional rationale supporting hypotheses $(\boldsymbol{B}-\boldsymbol{D})$ on the parallelism in responses, coupling and integration of the immune and psychological domain can be given by the existence of the generalized task of living organism survival (often "at the instinctive level"), and in the necessity of preparing (involving certain short- and long-term planning) to performing certain actions helping such survival. Initially e.g. in the processes of phylogenesis the immune and psychological domains have similar functionality and common tasks [32]:

- recognition of the threats;

- prognosis (forecast of the events);

- collection of data (recognition and fixation of the successful ways of problem solving and avoidance of the unsuccessful ones);

- counteracting threatening events (environmental changes) and minimizing damage caused by such.

Multiple related tasks are performed by the sensory systems of the living organism (sight, hearing, vestibular system etc.): signal detection, signal transfer and processing, signal encoding, constructing of the sensory image and sensory image recognition [34]. Signals coming from all major sensory systems supply information to the "common processing center" which assesses the status of the various living organism systems, their dynamics and the changes in the environment [34]. The immune and psychological domains are also reflecting the dynamics of the environment and, in some sense, safeguard the contacts between the living organism and its environment [32].

Sensory systems interact on the spinal, reticular, thalamic and cerebral levels [35]. Especially deep signal integration happens in the reticular formation. It is assumed that cortex is responsible for the "integration" of the incoming signals at the higher, perceptual level. As the result of multiple interconnections with other sensory and non-specific systems many of the neurons become responsive to the complex combinations of different stimuli $[34,36]$. Sensory information delivered to the brain is used for coordination of simple and complex responses and also forms what we call psychic activity [36, 37].

Interaction of the immune and psychic domains is intermediated by the neuroendocrine system [38-42]. Experimentally detected similarities of the cytokines secretion within the neural, immune and endocrinal systems, as well as the presence of elements of similar structures are symptomatic. These facts allow some researchers to speak of not only the similarities of these systems, but of possible interconnections between them and even of their possible integration (declaring that in fact these systems are the parts of a larger joint structure) [42-44].

Indications of the integration of supposedly different signaling systems strongly support hypotheses (B-D) on the parallelism in responses, coupling and integration of the immune and psychological domain, where the integration hypothesis (D) seems the most probable. Nature is surprisingly "rational" and in the course of evolution more general mechanisms, principles, solution that are effective for a whole range of different situations were generally preserved [43, 45]. Thus one can also broaden hypothesis $(\boldsymbol{D})$ and state, that what we call immune, psychic, neural and endocrine systems interconnected by multiple feedback and feedforward coupling loops presenting a larger joint meta-system. And different aspects of this metasystem are studied by different research disciplines from different points of view.

For the further hypotheses validation analysis of the results acquired from the experiments with laboratory animals was conducted (it is supposed that behavioral variability is much smaller in such experiments [46, 47]). Basing on the animal experiments data and numerous observations of human patients (For example, [1]), it is possible to conclude that psychological discomfort is influencing immune system. And the experiments with laboratory animals are quite valuable for the studies of the living organism reaction to the internal and external stimuli, to the physiological and psychological changes. For example, agnostic animal behavior is represented by a complex set of activities observed during the conflicts between the animals of the same species including threats and direct aggressions against the opponent (capacity to resist attack, active defense etc.) [47]. Demonstration of the submission, fleeing from the threat is attributed to the submissive (subordinate) type behavior [48]. These types of psychic reactions are regarded as belonging to the most generalized types of psychological defense mechanisms 
connected to the influence of the deeply congenital and reflex-based responses. One of the main foundations of such defense mechanisms is stereotyping, allowing other animals of the same species choosing effective strategies instinctively, by taking similar actions in similar situations.

Below we review the relevant experimental results acquired for the linear animals with the depressive state, with the observed changes happening at the different organizational levels. Many research activities today target the studies of the depressive states across the world. Depressions are unfortunately quite common for the humans of any age and for the representatives of all social groups. Depression today is diagnosed for about $10 \%$ of the population aged above 40 (almost two third of sufferers are women), and for about $30 \%$ of the population aged above 65 [49]. Also about 5\% of the children and teenagers aged from 10 to 16 years suffer from depression [49]. The studies of the depressive state are carried out worldwide, and significant amount of data is available. Experimental animals with the depressive state often used in such research are also a superb model for studying processes in psychic and immune domains.

\section{A. Behavioral Compensation of the Depression-like States}

Laboratory of Neurogenomics (Institute of Cytology and Genetics, Siberian Division of Russian Academy of Sciences) has selected a new line of laboratory mice, ASC ("antidepressant - sensitive catalepsy"). These mice are the result of backcross mating between the animals of the lines CBA and AKR. ASC mice in $85 \%$ cases express cataleptic reaction and have a tendency to catalepsy with a pronounced depression-like behavior, and are highly sensitive to the long-term exposure to the antidepressants [50, 51]. It was experimentally shown that depression-like behavior of these mice manifests itself as the reduction in the emotional activity and inquisitive activity in the open-field tests, and in the increased immobility time in the forced swimming tests and in the tail suspension tests [50]. It was also proven that catalepsy in such mice is more sensitive to the continuous rather than to the acute antidepressant administration, which coincides with the conclusions from the clinical observations over the human patients, where the significant clinical effect of the anti-depressants is observed only for their steady administration during long periods of time [51].

It is now assumed that cataleptic behavior is a certain natural form of the passive defense characteristic for the evolutionary early forms of the living organism behavior. This form of passive defense in laboratory mice is clearly connected to certain neurochemical and physiological changes [52], and also to the changes in the neural networks of the emotion genic hypothalamic-limbic reticular structures of the brain [53]. During cataleptic reaction certain localized areas of the cerebral cortex are "witching off", while the motor activity is present and is supported by the lower brain sections Suppression of the responses both to the internal and external stimuli are common in this state, which is supposedly connected to the endogenous suppression of the motor activity and with the concentration at the certain most intense stimulus. Catalepsy in humans is a common symptom of some severe neuropsychic dysfunctions such as schizophrenia and severe depression, and is also characterized by the changing immune status [18].

Thus one can interpret cataleptic reactions in laboratory mice to the open field and forced swimming experiments as a functional psychic reaction directed at minimization of the risks of the dangerously changing external conditions. This happens in attempt to reduce the psychic tension through the reduction of the sensory contacts with the environment. Such strategy realized within the psychic domain may be regarded as the passive form of the generalized defense strategy. In this case cataleptic behavior serves as an extreme form of minimization of visible motions, often together with the "camouflage" ("stealth") mode activated via the neurochemical and physiological changes as a reaction to the stressing factor, in a desperate attempt to become "invisible". Such behavior also makes sense as a "resource economy" strategy, as the majority of active response strategies (active motion, combating threat and adaptation to the changing environment) demand considerable energy expenditure. Resource economy ("preventing the depletion of vitality") is actually among the most fundamental living organism strategies [54]. This may be considered as an evolutional extension of the energy conservation laws of the inanimate matter towards the laws of animate matter [55, 56]. For example, in chemistry and biochemistry the reaction "pathways" mapped in the energy spaces take the routes with the minimal energy expenditures.

At a first glance, the energy expenditure approach to the parallelism of similar responses in two uncoupled or weakly coupled systems seems to be "evolutionary irrational", as two sub-systems seemingly are involved in duplicated actions. But even the "artificial evolution" of complex information-intense inanimate systems $[55,56]$ leads not only to the parallelism, but to the duplication and triplication of some system elements [57]. Such duplication, or redundancy, increases the stability of system operation in presence of disturbances and can keep such systems functioning under certain unrepaired damage [57, 58]. Such advanced "damage limitation" strategies can also provide certain evolutionary benefits.

Also, there is an experimentally detected effect of so-called cognitive bias in the anxiety-depression type of behavior, where anxious and depressive individuals tend to adopt a pessimistic interpretation of the external stimuli [59, 60]. So in these experiments behavioral patterns are also modulated by the consciousness. And this cognitive bias effect can be reversed by antidepressant application [60] indicating the modulation of the neuropsychiatric and behavioral effects through the biochemical input.

All in all the above discussions on the "evolutionary rationality" cannot provide any secure ground for declaring the parallelism hypothesis $(\boldsymbol{B})$ more or less probable compared to the coupling or integration hypotheses $(\boldsymbol{C}, \boldsymbol{D})$. But the 
coincidence hypothesis $(\boldsymbol{A})$ seems to be much less probable.

\section{B. Humoral-level Duplication of the System-level Depressive Behavior}

Inherited predisposition of the ASC mice to the catalepsy is also accompanied by the suppression of the immune response to the ram erythrocyte antigen, as compared to the parent CBA and AKR line mice [17, 61]. The state of an immune system was also studied for the C57B1/J6 mice with the acquired depressive behavior [19, 62]. The depressive behavior in such mice was developed as a reaction to the defeats from the more aggressive partners. Analysis of the immune response in such mice have shown that independently from the depression behavior formation time (10 or 20 confrontation days) the number of antibody forming IGM-cells at the peak of immune response was lower than in the control group (mice without defeats incidents). These experiments also confirm earlier results [63]. It is also shown that laboratory animals with depressive behavior have lower testosterone level and exhibit suppression of the cerebral dopamine activity against the background of the suppression of the humoral part of the immune system (suppressed synthesis of the humoral mediators) [63-65].

Analysis of the above experimental facts leads to the suggestion that reactions in the psychic domain targeting minimization of the environment- related threats (and expressed as the depressive behavior) are "reflected" into the immune domain (causing decreased immune response). Such visible connection between two domains is characteristic for the laboratory animals with both inherited and acquired predisposition to the depression and depressive behavior. One can interpret such reflection of the reactions from the psychic domain into the immune one as a part of complex congenital defense mechanism of the "passive distancing" with the aggressor. Within the psychic domain it is expressed as a depressive behavior (depression), and within the immune domain as a suppression of immune responses. Thus one can already speak about possible coupling directed from the psychic to the immune domain.

Certain connection between two discussed domains can also be interpreted from the information systems point of view. If each of the domains is regarded as the functional system treating incoming information and reacting to it, one can speculate that both systems somehow exchange the critical information. Special experiments were set up to answer the question if such exchange happens directly between two domains or both domains are controlled by the hierarchically higher system. Such experiments with the infected mice where the conscious reactions are minimized, allowed for certain direct answers [25]. Laboratory mice were infected by a relict microorganisms extracted from the 50 thousand-year-old archaic sediments. Infected animal behavior was assessed through open field experiments and compared with uninfected control. Infected animals appeared to have increased horizontal motion activity and increased immune responses (phagocytosis activation by spleen macrophages). This was accompanied by the decreased research activity and depression of the emotional state (grooming, defecation). It means that there exists a response within a psychic domain to the antigen type threat (and according to modern views psychic system has no appropriate sensors to detect such threats). Also such response exhibited as psychic anxiety results from the actions happening at different levels of organism protection. These resulted in the increased general undirected activity (unfounded orientation activity) and depressive behavior (generalized passive defense) over the background of immune domain activity suppression. One can speculate that increased undirected activity is a part of the reaction to an unrecognized threat from the environment, when the solution is searched for through a random location changing. Generalized protection strategies must counteract a widest variety of threats possible; thus the corresponding responses are commonly rather unspecific and undifferentiated.

One can thus speculate that psychic domain is in a sense immunocompetent as the psychic responses are involved in the generation of the system-level response (including the immune one) to the external threats. Moreover neural and endocrine systems seem to play a role of the "conductor" supervising the coordination of the whole "orchestra" of functional subsystems. In these coordinated activities of the overall "response system" psychic and immune domains have their sensorial specificity, with "psychics operating at the macro-level and immunity- at micro-level" [32]. Basing on the above authors of [32] proposed an idea of the possible functional isomorphism between the psychic and immune domains.

Referring to the hypotheses formulated above, discussed experimental results support the parallelism, coupling or integration hypotheses (B-D). And the coincidence hypothesis (A) seems less and less probable.

\section{Cellular-level Effects of the Social Defeats}

In the experimental studies with laboratory mice submissive (subordinate) type behavior was developed using the method of distant sensorial contacts with prolonged confrontations [47, 66-68]. Aggressive and submissive type animals were kept in the adjacent sections of a special cage with removable partition. Every day through the duration of experiment this separating partition was removed for 10 minutes and animal contacts were monitored. It was possible to distinguish two stages of submissive behavior development depending on the history of social defeats. The first stage, "depression onset" was forming roughly to the 10th day, and the second stage, "developed depression" was forming roughly to the 20th day of the confrontations [47]. It was found that for the laboratory mice (line C57B1/6J) the number of suppressor CD8+ T-lymphocytes in the bone marrow steadily increased up to the 10th day of the confrontations ("depression onset" stage) while the number of the helpers CD4+ T- cells was unchanged (as compared to the control) [67]. It was also observed, that the number of suppressor CD8+ T- cells in the bone marrow measured at the 20th day of confrontations ("developed depression" stage) was increasing not only as compared to the control, but to the mice with 10-day history of confrontations as well [68]. It was also 
observed that for the rats the numbers of T-lymphocytes (CD8+) in the periphery blood was decreasing after 2-hour social defeats [69].

Thus one can conclude that the intensity of immune system reaction detected at the cellular level follows the intensity and duration of the induced stress. In general, the decrease in the numbers of suppressors (T-lymphocytes) in the periphery blood of the laboratory animals is detected already in the first hours from the onset of the external threats, and the increase of their numbers in the bone marrow is observed after prolonged exposure to the external threats (prolonged stresses). Thus two mechanisms seem to be involved in the process. One of them (leading to the decreased numbers of suppressors in the blood) seems to be involved into the "rapid response" measures, while another (leading to the increased numbers of suppressors in the bone marrow) is involved with the long-term defenses. Thus the immune system (cellular level) is capable of supporting both rapid and prolonged reactions in counteracting the external aggression.

Constructing analogies between the strategies of immune-cellular and psychic domains functionality one can recognize certain similarities in the basic congenital active defense mechanisms: "monitoring, control, rejection". In the psychic domain individual behavioral pattern is formed as a reaction on the prolonged external aggression [71]. In turn, the immune domain responds with the changes in functional activity of cell populations and migratory properties of lymphocytes, which is made possible through changing activity of neuromediator systems of the brain [72].

It is also established that submissive laboratory animals with 20-day confrontation history have increased levels of corticosteroids and decreased levels of the blood testosterone [73]. It is natural to presume that these are the consequences of immune system suppression, caused by changing glucocorticoid and serotonin levels, and the suppressed immunostimulatory effects caused by changing testosterone and dopamine levels [74]. Earlier it was observed that the correlation between immune activity and testosterone level impacts the reproductivity and survival rates trough increasing adaptability of the animals [75]. Such correlation was demonstrated for many animal species and for humans [76], though for submissive type animals this evolutionary strategy "acts in opposite direction" [77, 78].

One can say that psychic and immune domains evolutionary formed similarly functioning mechanisms and behavioral patterns providing multi-level defenses and developing new (non-inherited) strategies preventing living organism from the damage and overloads. Other systems of the organism, like neural and endocrine ones also seem to take active part in the defense. And if we still treat the immune and psychic systems as fairly independent subsystems, we should conclude that psychosomatic regulation of the living organism is carried out via the immune neuroendocrine regulation, and functional dynamics of one subsystem is modulated by the state and dynamics of the other one. On the other hand, one can treat the above findings as supporting the suggestion that immune and psychic domains are somehow strongly connected or integrated, and possibly are hardly separable in context of our discussions (if at all) into two subsystems.

Referring to the hypotheses formulated above, discussed experimental results support the coupling or integration hypotheses $(\mathbf{C}, \mathbf{D})$. And the parallelism and coincidence hypothesis (A, B) seem much less probable.

\section{Organ-level Compensation of the Behavioral Depression}

In the experiments with the submissive animals (male mice, line C57B1/6J) after continuous defeats in the male-male confrontations (20 days) significant changes were detected in the immunocompetent organs [74]. For example, significant decrease in the CD3+, CD4+ and CD8+ lymphocyte numbers as compared to the control was detected in the thymus. Decrease in the CD3+ and CD8+ lymphocyte numbers, and CD4+ and CD25+ lymphocyte relative numbers were detected in the spleen. Simultaneously the CD8+ suppressor cell numbers were increasing in the lymphatic nodes.

According to the opinion expressed in [73] for the well onset depressive state the immune system suppression has the central origin, e.g. is connected to the dysfunction in the central (thymic) differentiation of the T-lymphocytes caused by the changes in the serotonergic and dopaminergic systems. Here we can see another confirmation of the psychic and immune systems connections to the neural and endocrine systems. And again, one can speculate that psychic, immune and endocrine systems are seemingly the integral parts of a complex meta-system with numerous feedforward and feedback coupling loops. This forms additional arguments supporting the coupling or integration hypotheses $(\boldsymbol{C}, \boldsymbol{D})$.

If psychic and immune domains are indeed coupled than the signals about the threat are channeled to all subsystems of this "block", and the activation of the psychic defense mechanisms is causing the activation of the immune defenses and probably vice versa. Thus it looks likely that within this common "block" multiple defense mechanisms are invoked as the result of external signals from the threat, providing both a "rapid response" actions (functional resonance mechanisms) and various special counteraction measures basing on the detailed analysis of the situation (structural resonance mechanism). This is a strategy of "defending by all possible means" necessary for protection of the very existence of the living organism [32].

In the experiments described above it was also detected that cellular resources are re-distributed within major organs to benefit not only the immune response but also the other major bodily systems. Re-distribution of the cells from thymus, spleen and lymphatic nodes may be due to the shift in the neurochemical balance in the cerebral system towards the activation of the serotonergic system (it is known that such activation is accompanied by the decreasing activity of the T-lymphocytes [79, 80]). The same time the increasing number of the T-lymphocytes in the spleen and lymphatic nodes (CD4+ and CD25+ in the spleen 
and CD8+ in the lymphatic nodes correspondingly) is regarded to be an indicator of activation of the general serotonin-induced immune reactions resulting from the local skin damage happening during laboratory animal confrontations [81].

Applying some common terminology, it looks that higher-level systems (organ level in this particular case) have a possibility of redistributing certain resources for most efficient defense. This can only happen if "situation monitoring" exists at the organ level, when higher-level systems monitor the efficiency and control the performance of the lower-level subsystems. And such monitoring and regulation involves both biochemical and cell-level mechanisms. Thus psychic and immune domains are hardly independent, and the higher level meta-system is hardly a simple sum of these two. Earlier results already prompted the suggestions that there is certain isomorphism in the functioning of the psychic and immune systems [31, 82], and both are involved in the mechanisms of homeostasis/ homeorhesis [28, 29, 31, 83] providing regulatory mechanisms at the system level. This in turn is supported by multiple dependent, independent and partially redundant feedback and feedforward control loops with the possibilities of partial hyper-activation and passivation (suppression) of some of the regulatory mechanisms. Thus psychic and immune domains are at least deeply integrated and complementary, with the capacity to certain synchronism and to delegation of certain monitoring and control functions across the domains. Again, from the point of view of "least complexity" it is feasible that we are dealing with some more or less integrated meta-system with united, rather than parallel response mechanisms.

The depth of involvement of and coordination between the psychic and immune domains in counteracting the external threats strengthens the idea that these two systems, in fact belonging to a unified complex meta-system. And their separation is mainly a historic event, an early step in generating of the two classes of models (psychic and immune) designed to study different aspects of functioning of this meta-system. As long as these initial purposes for model classes are kept both of them are adequate, and they cannot be regarded as either contradictory or not contradictory to each other by the nature of their design. So in a sense we are trying to answer a wrong question. But when the studies of our meta-system come to a certain level of complexity (and it seems that this level is reached) the revision of modeling approach is due to happen. Such revision must not doubt the achievements of either classes of the models (psychic and immune domains), but must provide a new model class, capable of not only absorbing the achievements of already existing classes, but of in-depth description of facts, processes, dynamics of the meta-system, which is not possible by any of the existing classes separately or by using simple "sum" of their results.

Referring to the hypotheses formulated above, discussed experimental results support the coupling $(\boldsymbol{C})$ or integration hypotheses $(\boldsymbol{D})$, and the latter seems more probable. And the parallelism and coincidence hypothesis $(\boldsymbol{A}, \boldsymbol{B})$ seem much less probable.

\section{CONCLUSIONS}

Present paper describes the approach to the immunology and psychology from the formal-modeling point of view, rather than using the dominating paradigms from within each of the respective domains. It allows performing critical analysis of the experimental facts pointing out to certain similarities in the dynamics of the psychic and immune processes in the course of supporting life, which can be hard to explain from within each of respective domains. Following this formal pathway it is possible to conclude that the direct attempts to use these two classes separately for the explanation of certain experimental results are not fruitful as we are trying to reach beyond the scope of validity for each respective model class. The situation is also some burdened by the attempts of either directly joining these two very different model classes, or by trying to make direct comparison between them. Basing on the formal-modeling approach we can conclude that it is possible to find a way out from these often highly visible but nevertheless imaginary paradoxes. Thus one should accept that none of the model classes will be able to describe certain facts lying beyond the validity domain of corresponding model classes and outside the initially chosen tasks, which these model classes were created for solving. To explain such facts, one need to construct a new class of models combining the achievements of both existing classes, starting from formulating the tasks for this new model, making new assumptions and simplifications to the overall picture we have on the functioning of the living organism and so on. This is of course a huge task for the future. Nevertheless, certain particular outcomes of the analysis can be useful already today.

1. One should clearly separate the models (psychology and immunology) describing certain processes within the living organism from the subjects (the processes and their experimentally recorded manifestations). Even if one is dealing with actually separable subsystems (psychological and immune) of the larger meta-system (living organism) it is not proper to conceptually substitute the subsystem itself by its model and vice versa.

2. Acquired experimental data indicate that psychic and immune domains are hardly separable in performing their major functions, stressing the suggestion that psychology and immunology are describing certain aspects of functioning of the same complex system (living organism) from different points of view. And certain imaginative paradoxes can appear when these two are describing one and the same aspect, event or process.

3. For proper discussions on the interrelation of the immunity and psychology one should rather follow a generalized modeling approach, speaking about two descriptive and prognostic classes of models developed for different purposes within different areas of science. Generalized functionality approach, discussing the functioning of large meta-system "living organism", outlining certain functionality-oriented subsystems and functional modules without attributing these explicitly to 
either immunity or psychology domain, seems to be much more productive. But applying the formal modeling approach one can conclude that this is in essence again nothing else than functional modeling. In such capacity, functionality-modeling approach can provide a pathway for developing new, is more comprehensive class of generalized models for studying dynamic responses of the living organisms.

4. Known experimental data concerning interrelations of the immune and psychic domains were analyzed following the formal logic pathway. Four hypotheses were stated on such interrelation:

a. Psychic and immune domains are reflecting two independent functionally separable subsystems within living organism, and experimental results pointing to certain similarity or parallelism in their dynamics reflecting external influences (threats) are due to a coincidence;

b. Psychic and immune domains are reflecting two independent functionally separable subsystems coupled to a third, hierarchically superior subsystem, which "drives" immune and psychic subsystems causing parallelism in dynamic responses;

c. Psychic and immune domains are reflecting two independent functionally separable subsystems coupled directly, or at least partly integrated, thus dynamic reactions in each of them will directly depend on the state and dynamics in the other;

d. Psychic and immune domains are just two classes of models describing complex dynamics of the large meta-system "living organism" and their separation is only done for the purpose of modeling. In such case separation of domains as well as certain functional blocks within both of them may be strongly dependent on the point of view, and at any rate cannot be regarded as contradictive.

Known experimental data were analyzed with the task of finding arguments for the validity of each of the above hypotheses in hope to select the most probable one.

5. Experiments with cataleptic and submissive laboratory animals can be regarded as a good model to assess the validity of stated hypotheses. Following general conclusions can be drawn analyzing corresponding experiments with laboratory animals, and known data from human patients.

a. Catalepsy and decreasing behavioral reaction intensity for the mice in depression-like states can be treated as a behavioral compensation mechanism, e.g. a psychic reaction targeting minimization of the risks and threats coming from outside world (environment). One can regard this strategy as a passive form of the generalized defense. In this strategy living organism can realize different forms of "withdrawal" reactions, starting from distancing from and ignoring the opponent, as well as different levels of the situation assessment, like threat discrediting and perceptional blindness. Active defense and specific concentration at threat tackling demand additional energy consumption, so passive defense strategies may be evolutionary beneficial as the one minimizing "energy expenditure".

b. Treating the immune and psychic domains traditionally, e.g. as separate subsystems, one can suppose that in general terms of the actions these subsystems target the support of behavioral strategies. Behavior is one of the major dynamic processes of the living organism determining its well being and survival. Traditionally the psychic activity is assumed to be integrally linked to the behavioral patterns. And in such sense other subsystems should provide the support to behavioral strategies. But at the deeper level, both psychic and immune domains involve mechanisms controlled by the neural and chemical signaling.

c. Dynamics of the processes traditionally attributed explicitly to either psychic or immune domains carry the features of at least certain parallelism. Basing on traditional approach of the separate immune and psychic subsystems above conclusion points out to the existence of at least certain coupling between the two. If we suppose that these two subsystems are independent, we should accept that in the course of evolution they have developed similar regulatory mechanisms of the reaction to the same external perturbations invoked by external threats and acting in parallel. And these mechanisms are going rather "deep", at least down to the cellular level. Though such possibility cannot be disregarded it seems much less probable than the possibility of coupling between two subsystems or their at least partial integration.

6. Analysis of the experimental data available today does not allow declaring one of the formulated hypotheses to be "a clear winner". But the majority of collected facts lead to the conclusion that psychic and immune domains cannot be treated as independent and similarity in the reaction dynamics is not a coincidence in the context of survival strategies and behavioral dynamics of the responses to external threats (e.g. the probability of hypotheses a and b being correct is low). Thus there is a necessity to look deeper into the nature of such coupling (hypotheses $\mathbf{C}, \mathbf{D}$ ) or suggest other alternatives.

7. Basing on the known experimental facts one can formulate a formal logic-based approach, also related to the formal modeling point of view. Here we can accept that psychic and immune domains are represented by two classes of models, both describing the dynamics of one and the same meta-system "living organism" or one of its large subsystems. And thus the separation of the psychic and immune subsystems and their functional blocks is to the large extent imaginary, made to simplify 
the picture of the overall system dynamics for the modeling purposes. Corresponding model classes already became extremely reach in details and both cover multiple hierarchical levels down to elementary biochemical signaling. But they were essentially created for certain research and prognostic tasks (which were initially quite different) and even use own metalanguages. Within this approach any attempts to explain the facts falling out of the scope of these models from within each of the classes, as well as their direct simplistic comparison are fruitless and potentially erroneous.

8. A certain body of experimental facts acquired to the moment outlines the appearing inadequacies in formal separation of psychic and immune domains. Thus there is a necessity in constructing of new model classes, describing the dynamic processes traditionally attributed separately to the immune and psychic domains in a coordinated way, preserving the achievements of both modeling approaches. Such new construction demands clear understanding of the purposes of this new class of models. This new class should adequately explain all existing body of experimental data in all cases, including the ones where existing classes of models separately or as a "simple sum" are inadequate. Only in such case it would be possible to use newly constructed models for the prognostic purposes. One of the challenging areas for testing such models can be the modeling and explaining of behavioral mechanisms combating external threats.

Current paper outlines certain critical issues existing today in hope for initializing open discussion of the specialists in both immunology and psychology. Outlined hypotheses still await proper in-depth analysis, but suggested approach may provide a path forward. And new experiments set up to prove or disprove formulated hypothesis will definitely contribute to better understanding of the dynamic responses of the living systems to changes in their environment.

\section{REFERENCES}

[1] D. Gutmann, "Thoughts on the Late-Onset Disorders," presented at the Conference on Mental Health and Aging, Tel-Aviv University, 1995. [Online]. Available: http://isites.harvard.edu/fs/docs/icb.topic40747.files/PsychImmSys_LOD.pdf.

[2] J. Decety and P. L. Jackson, "The functional architecture of human empathy," Behavioral and Cognitive Neuroscience Reviews, vol. 3, no. 2, pp. 71-100, June 2004.

[3] E. Sundstrom, "Physical environment and interpersonal behaviour," In: Social psychology in the eighties, 4th ed., K. Deaux and L. Wrightsman Ed., Monterey, CA: Brooks/Cole, 1984.

[4] E.J. Kunkel and E.C. Butcher, "Chemokines and the tissue-specific migration of lymphocytes," Immunity, vol. 16, iss. 1, pp. 1-4, 2002.

[5] J. Peter, Encyclopedia of Immunology, Delves Ed., Academic Press, 1998.

[6] W. E. Paul, Fundamental Immunology, Lippincott Williams \& Wilkins, 2012.

[7] B. P. Zeigler, T. C. Kim, and H. Praehofer, Theory of Modeling and Simulation, 2nd ed., Academic Press, 2000.

[8] R. L. Winslow, N. Trayanova, D. Geman, and M. I. Miller, “Computational Medicine: Translating Models to Clinical Care,” Sci. Transl. Med., vol. 4, iss. 158, 158rv11, Oct. 2012.

[9] J. Sokolowski and C. Banks, Modeling and Simulation Fundamentals: Theoretical Underpinnings and Practical Domains, Wiley, 2010.

[10] S. Robinson, "Modes of simulation practice: approaches to business and military simulation," Simulation Modelling Practice and Theory, vol. 10, iss. 8, pp. 513-523, Jan. 2002.

[11] T. Ritchey, "Outline for a Morphology of Modelling Methods. Contribution to a General Theory of Modelling," Acta Morphologica Generalis, vol. 1, iss. 1, pp. 1-20, 2012. [Online]. Available: http://www.amg.swemorph.com/pdf/amg-1-1-2012.pdf.

[12] C. W. Churchman, The Systems Approach, New York: Dell Publishing, 1968.

[13] R. C. Hichson and J. B. Bonne, Stress and Immunity, pp. 211-234, Boca Raton, 1991.

[14] T. Kizaki, H. Yamashita, S. Oh-Ishi, N. K. Day, R. A. Good, and H. Ohno, "Immunomodulation by cells of mononuclear phagocyte lineage in acute cold-stressed or cold-acclimatized mice," Immunology, vol. 86, iss. 3, pp. 456-462, Nov. 1995.

[15] A. Nakata, S. Araki, T. Tanigawa, S. Sakurai, and M. Yokoyama, "Effects of uncontrollable and controllable electric shocks on T lymphocyte subpopulations in the peripheral blood, spleen, and thymus of rats," Neuroimmunomodulation, vol. 3, iss. 6, pp. 336-341, November-December 1996.

[16] V. V. Chirkin, V. I. Kandrashev, and F. N. Palev, Immunorehabilitation (pathophysiological and clinical aspects), p. 124, Moscow, Medicine, 2003. (In Russian: Чиркин В.В., Карандошов В.И., Палеев Ф.Н. Иммунореабилитация (патофизиологические и клинические аспекты), М.: Медицина, с. 124, 2003).

[17] L. V. Devojno, E. L. Alperina, N. N. Kudrjavtceva, and N. K. Popova, "Changes in the immune response in male mice with aggressive and submissive behaviour,” Physiologicheskij Jurnal imeni Sechenova, vol. 77, iss. 12, pp. 62-67, 1991. (In Russian: Девойно Л.В., Альперина Е.Л. Кудрявцева Н.Н., Попова Н.К., Изменение имунного ответа у мышей самцов с агрессивным и субмиссивным типами поведения. Физиол. журн. им. Сеченова, т. 77, № 12. с. 62-67, 1991).

[18] L. Capuron, A. H. Miller, and M. Irwin, Psychoneuroimmunology of depressive disorder: Mechanisms and clinical implications, In: Ader, R. Ed., Psychoneuroimmunology, 4th ed., pp. 509-530, 2007.

[19] E. L. Alperina and T. A. Pavina "Changing the immunological reactivity in C57B1/6J mice under zoosocial conflict," Bulleten Experimentalnoj Biologii i Mediciny, vol. 122, iss. 11, pp. 541-543, 1996. (in Russian: Альперина Е.Л., Павина Т.А. “Изменение иммунологической реактивности у мышей линии С57B1/6J в условиях зоосоциального конфликта,” Бюл. эксперим. биол. и мед. 1996. т. 122. № 11. c. 541-543).

[20] M. Lyte, S. G. Nelson, and M. L. Thompson, "Innate and adaptive immune responses in a social conflict paradigm," Clinical Immunology and Immunopathology, vol. 57, iss. 1, pp. 137-147, 1990. 
[21] E. Fano, J. R. Sanchex-Martin, A. Arregi, B. Castro, A. Alonso, P. Brain, and A. Azpíroz, "Social stress paradigms in male mice: Variations in behavior, stress and immunology," Physiol. Behav., vol. 73, iss. 1-2, pp. 165-173, 2001.

[22] N. K. Popova, A. V. Kulikov, D. F. Avgustinovich, G. B. Vishnevrtskaya, and V. G. Kolpakov, "Participation of 5-HTiA serotonin receptors in the brain in the regulation of hereditary catalepsy," Bulleten Experimentalnoj Biologii i Mediciny, vol. 118, pp. 633-635, 1994. (In Russian: Попова Н.К., Куликов А.В., Августинович Д.Ф., Вишнивецкая Г.Б., Колпаков В.Г., "Участие 5-НТіА серотониновых рецепторов головного мозга в регуляции наследственной каталепсии,” Бюлл. Экспер. Биол. Мед., 1994. т. 118. с. 633-635).

[23] V. Stefanski, "Social stress in laboratory rats: hormonal responses and immune cell distribution," Psychoneuroendocrinology, vol. 25, iss. 4, pp. 389-406, 2000.

[24] M. V. Bogdanova, "Specifics of the psychological defence in psychosomatic disorders," PhD Thesis (Doctor of Psychology), Tyumen State University, Tyumen, Russia, 2005. (In Russian: Богданова М.В. Особенности психологических защит при психосамотических расстройствах. Дисс. канд. Психол. Наук. 2005).

[25] E.V. Docenko and T. A. Fisher, "Psychosomatic reactions to the introduction of microorganisms into mice," Bulleten Tyumenskogo Gosudarstvennogo Universiteta, vol. 5, pp. 120-128, 2010. (In Russian: Доценко Е.В., Фишер Т.А. Психосоматические реакции мышей на введение микроорганизмов. Вестник Тюменского Государственного Университета, 2010 (5), с. 120-128).

[26] T. A. Fisher, E.V. Docenko, and S. A. Petrov, "Psychological and immune responses to short-term cold exposure," Vestnik Uralskoj Akademicheskoj Nauki, iss. 4, pp. 66-67, 2012. (In Russian: Фишер Т.А., Доценко Е.Л., Петров С.А., "Психологические и иммунные реакции на кратковременное холодовое воздействие”, Вестник Уральской медицинской академической науки, 2012, № 4. c. 66-67).

[27] C. Pittenger and R. S. Duman, "Stress, Depression, and Neuroplasticity: A Convergence of Mechanisms," Neuropsychopharmacology, vol. 33, pp. 88-109, 2008.

[28] S. Chourbaji, C. Brandwein, and P. Gass, "Altering BDNF expression by genetics and/or environment: Impact for emotional and depression-like behaviour in laboratory mice," Review, Neuroscience \& Biobehavioral Reviews, vol. 35, iss. 3, pp. 599-611, 2011.

[29] W.B. Cannon, "Organization for physiological homeostasis," Physiological Rev., vol. 9, iss. 3, pp. 399-431, 1929. [Online]. Available: http://physrev.physiology.org/content/9/3/399.full.pdf+html.

[30] M. Ferencik and V. Stvrtinova, "Is the immune system our sixth sense," Bratisl. Lek. Listy., vol. 98, iss. 4, pp. 187-198, 1997 (in Slovak).

[31] C.H. Waddington, The Strategy of the Genes: A Discussion of Some Aspects of Theoretical Biology, George Allen and Unwin, London, 1957.

[32] Yu. G. Sukhovey and E. L. Docenko, "Immanence and isomorphism of psychic and the immune systems," Vestnik Uralskoj Akademicheskoj Nauki, iss. 4, pp. 62-63, 2012. (In Russian: Суховей Ю.Г., Доценко Е.Л. Имманентность и изоморфность психики и иммунной системы. Вестник Уральской медииинской академической науки. 2012, № 4 с. 62-63).

[33] E. G. Camara and T. C. Danao, "The brain and the immune system: A psychosomatic network," Psychosomatics, vol. 30, iss. 2, pp. 140-146, 1989.

[34] J. T. Cacioppo and L. G. Tassinary, Principles of psychophysiology: Physical, social, and inferential elements, Cambridge: Cambridge University Press, 1990.

[35] M. Breedlove, M. Rosenzweig, and V. Neil, An Introduction to Behavioral and Cognitive Neuroscience, Sinauer Associates, Watson, Biological Psychology, 2007.

[36] C. Smith, Biology of Sensory Systems, 2nd ed., Willey- Blackwell, 2009.

[37] D. H. Hubel, Eye, Brain, and Vision, Scientific American Library Series, 2nd ed., Henry Holt and Co, 1995.

[38] L. S. Berk, D. L. Felten, S. A. Tan, B. B. Bittman, and J. Westengard, "Modulation of neuroimmune parameters during the eustress of humor-associated mirthful laughter," Altern. Ther. Health. Med., vol. 7, iss. 2, pp. 62-76, 2001.

[39] G. V. Idova, E. L. Alperina, M. A. Chejdo, S. M. Kuznetsova, E. N. Zhukova, and D. V. Yurjev, "Neuroimmune interactions under psycho-emotional stress," Bulleten Sibirskogo Otdelenija RAMN, vol. 30, iss. 4, pp. 31-37, 2010. (In Russian: Идова Г.В. Альперина Е.Л. и др., "Нейроиммунные взимодействия при психоэмоциональном напряжении (экспериментальное исследование)", Бюллетень СО РАМН, т. 30, № 4, 2010. с. 31-37).

[40] G. J. Wood, S. Bughi, J. Morrison, S. Tanavoli, and H. H. Zadeh, "Hypnosis, differential expression of cytokines by T-cell subsets, and the hypothalamo-pituitary-adrenal axis," The American journal of clinical hypnosis, vol. 45, iss. 3, pp. 179-196, 2003.

[41] V. V. Abramov, "Possible principles of integration of the immune and neuroendocrine systems," Immunologija, iss. 1, pp. 60-61, 1996. (In Russian: Абрамов В. В., “Возможные принципы интеграции иммунной и нейроэндокринной систем,” Иммунология. - 1996. № 1. - c. 60-61).

[42] V. V. Abramov, E. V. Markova, N. A Korotkova, and V. A. Kozlov, "Modulation of orientation and exploratory behavior of CBAxC57BI/6 mice by F1 immunocompetent cells," Bulleten Experimentalnoj Biologii i Mediciny, vol. 134, iss. 9, pp. 319-21, 2002. (In Russian: Абрамов В.В. Маркова Е. В., Короткова Н. А., Козлов В. А. “Модуляция ориентировочно-исследовательского поведения мышей (CBAхC57BI/6)F1 иммунокомпетентными клетками”. Бюллетень экспериментальной биологии и медицины. 2002. 134 (9): 319-321).

[43] Psychoneuroimmunology, R. Ader, D. L. Felten, N. Cohen, Ed., Acad. Press, San Diego, 1991.

[44] A. B. Poletaev, "Autoantibodies as a universal modulator of biological functions," Proc. The 1st Intern. Workshop Proc Bio-Molecular Medicine-200: In search of Approaches, Moscow, pp. 42-48, 1993.

[45] A. Mazur and A. Booth, "Testosterone and dominance in men," Behav Brain Sci., vol. 21, iss. 3, pp. 353-397, 1998.

[46] N. N. Kudrjavtseva, I. A. Dolganov, P. P. Bondar, and D. F. Avgustinovich, "Effect of selective antagonist to the $\mu$-opioid receptor 
Dago on hostile and anxious behavior in male mice with different experience of aggression," Jurnal Vyschej Nervnoj Dejatelnosti, vol. 53, iss. 1, pp. 81-87, 2003. (In Russian: Кудрявцева Н.Н., Долганов И.А., Бондарь П.П., Августинович Д.Ф. Влияние селективного антагониста $\mu$-опиоидных рецепторов Dago на враждебное и тревожное поведение самцов мышей с разным опытом агрессии. Журнал высшей нервной деятельности. 2003. 53 (1): 81-87).

[47] N. N. Kudryavtseva, "Psychopathology of repeated aggression: a neurobiological aspect," In: Morgan J.P., Ed., Perspectives on the Psychology of Aggression, NOVA Science Publishers Inc., 2006.

[48] V. F. Avgustinovich, O. V. Alekseenko, and I. V. Baktashtanovskaya, "Dynamic changes in serotonin and dopamine-related activity in the brain during development of anxious depression: an experimental study," Uspehi Physiologicheskih nauk, vol. 35, iss. 4, pp. 19-40, 2004. (In Russian: Августинович, В.Ф., Алексеенко О.В., Бакташтановская И.В. Динамические изменения серетонической и дофаминергической активности мозга в процессе развития тревожной депрессии: экспериментальное исследование. Усnехи физиологических наук. 2004. 35 (4): 19-40).

[49] M. H. Rapaport, L. L. Judd, P. J. Schettler, K. A. Yonkers, M. E. Thase, D. J. Kupfer, E. Frank, J. M. Plewes, G. D. Tollefson, and A. J. Rush, "A descriptive analysis of minor depression," American Journal of Psychiatry, vol. 159, iss. 4, pp. 637-643, 2002.

[50] D. V. Bazovkina, A. V. Kulikova, E. M. Konduarova, and I. K. Popova, "Selective breeding for predisposition to depression-like behavior enhances catalepsy in mice," Genetika, vol. 41, iss. 9, pp. 1-6, 2005. (In Russian: Базовкина Д.В., Куликова А.В., Кондаурова Е.М., Попова И.К. Селекция на предрасположенность к каталепсии усиливает депрессивноподобное поведение у мышей. Генетика. 2005. 41 (9): 1-6).

[51] M. A. Tihonova, V. V. Lebedeva, D. V. Bazovkina, and N. K Popova, "The imipramine effect on the behaviour and 5-HT1A serotonin receptors in the brain of mice with a genetic predisposition to the fading," Bulleten Experimentalnoj Biologii i Mediciny, vol. 141, iss. 1, pp. 53-55, 2006. (In Russian: Тихонова М.А., Лебедева В.В., Куликов А.В., Базовкина Д.В., Попова Н.К. “Эффект имипрамина на поведение и 5-НT1А-серотониновые рецепторы мозга у мышей с генетической предрасположенностью к реакции замирания", Бюл. экспер. биол. мед. 2006. т. 141. № 1. с. 53-55).

[52] V. G. Kolpakov, A. V. Kulikov, T. A. Alehina, V. F. Chuguj, O. I. Petrenko, and N. N. Barykina, "Catatonia or depression? Line GC rats - genetic animal model of psychopathology,” Genetika, vol. 40, iss. 6, pp. 1-7, 2004. (In Russian: Колпаков В.Г., Куликов А.В., Алехина Т.А., Чугуй В.Ф., Петренко О.И., Барыкина Н.Н. "Кататония или депрессия? Линия крыс ГК - генетическая животная модель психопатологии," Генетика, 2004. 40 (6): 1-7).

[53] R. Landgraf, A. Wigger, F. Holsboer, and I. D. Neumann, "Hyper-reactive hypothalamo-pituitary-adrenocortical axis in rats bred for high anxiety-related behaviour," J. Neuroendocrinol., vol. 11, iss. 6, pp. 405-407, June 1999.

[54] C. R .Martell, M. E. Addis, and N. S. Jacobson, Depression in Context: Strategies for Guided Action, W.W. Norton, New York, 2001.

[55] S. Lem, Summa Technologiae, Minneapolis: University of Minnesota Press, 2013.

[56] P. Saunders, “The Organism as a Dynamical System," In: Thinking about Biology, SFI Studies in the Sciences of Complexity, Lecture Notes, vol III, F. Varela and W. Stein, Ed., Addison Wesley, Reading, pp. 41-63, 1993. [Online] Available: http://www.mth.kcl.ac.uk/staff/pt_saunders/SFI_NoEL.pdf.

[57] J. Downer, "When Failure is an Option: Redundancy, reliability and regulation in complex technical systems," Discussion Paper No 53, 2009, London School of Economics and Political Sciences, Center for Analysis of Risk and Regulation. ISBN: 9780853283959. [Online] Available: http://www.lse.ac.uk/researchAndExpertise/units/CARR/pdf/DPs/Disspaper53.pdf.

[58] A. J. Cunningham, "A Method of Increased Sensitivity for detecting Single Antibody-forming Cells," Letters to Nature, vol. 207, pp. 1106-1107, 1965.

[59] A. L. Salmeto, K A. Hymel, E C. Carpenter, B. O. Brilot, M. Bateson, and K. J. Sufka, "Cognitive bias in the chick anxiety-depression model," Brain Research, vol. 1373, pp. 124-130, 2011.

[60] K. A. Hymel and K. J. Sufka, "Pharmacological reversal of cognitive bias in the chick anxiety-depression model," Neuropharmacology, vol. 62, iss. 1, pp. 161-166, 2012.

[61] G. V. Idova, D. V. Yurjev, E. N. Zhukova, and S. M. Kuznetcova, "Immune response of the pre- and post-serotonin receptors 5-HT for the C57BL/6J mice at different depressive state development stages," Bulleten Eksperimentalnoj Biologii i Mediciny, vol. 151, iss. 3, pp. 331-333, 2011. (In Russian: Идова Г.В., Юрьев Д.В., Жукова Е.Н., Кузнецова С.М. “Иммунный ответ при активации Пре- и постсинаптических серотониновых 5-НT - рецепторов у мышей линии C57BL/6J на различных стадиях развития депрессивноподобного состояния", Бюллетень эксперементальной биологии и медицины. 2011. 151 (3): 331-333).

[62] L. V. Devojno, G. V. Idova, and E. L. Alperina, Psychic-immunomodulation, behaviour and immunity. The role of "neuromediatorial setting” of the brain, Novosibirsk, 2009. (In Russian: Девойно Л.В., Идова Г.В., Альперина Е.Л. Психонейроиммуномодулящия и поведение и иммунитет. Роль «нейромедиаторной» установки мозга. Новосибирск, 2009).

[63] O. V. Alekseenko, D. F. Avgustinovich, and T. V. Lipina, "Participation of D1 and D2 dopamine receptors in the brain during development of depression caused by social confrontations in mice," Jurnal Vysshej Nervno Dejatelnosti, vol. 48, iss. 6, pp. 1090-1098, 1998. (In Russian: Алексеенко О.В., Августинович Д.Ф., Липина Т.В. “Участие D1 и D2 дофаминовых рецепторов мозга в процессе развития депрессии, индуцированной социальными конфронтациями у мышей”. Журнал высшей нервной деятельности. 1998; 48 (6): 1090-1098).

[64] D. Misdrahi, M. C. Pardon, F. Pérez-Diaz, N. Hanoun, and C. Cohen-Salmon, "Prepartum chronic ultramild stress increases corticosterone and estradiol levels in gestating mice: implications for postpartum depressive disorders," Psychiatry Res., vol. 137, iss. 12, pp. 123-130, 2005.

[65] S. A. Johnson, N. M. Fournier, and L. E. Kalynchuk, "Effect of different doses of corticosterone on depression-like behavior and HPA axis responses to a novel stressor," Behavioural Brain Research, vol. 168, iss. 2, pp. 280-288, 2006.

[66] I. V. Bashkatanovskaya and N. N. Kudrjavtseva, "Strategy of submissive behaviour in male mice: effect of genotype and previous experience of agonistic interactions," Jurnal Biologicheskih Nauk, iss. 11, pp. 73-79, 1991. (In Russian: Бакташтановская И.В., 
Кудрявцева Н.Н., “Стратегия субмисивного поведения самцов мышей: влияние генотипа и опыта предшествующих агонистических взаимодействий,” Журнал биологических наук. 1991. № 11. с. 73-79).

[67] N. N. Kudrjavtseva and I. V. Bashkatanovskaya, "The neurochemical control of aggression and submission," Jurnal Vysshej Nervnoj Dejatelnosti, vol. 41, iss. 5, pp. 459-466, 1991 (In Russian: Кудрявцева Н.Н., Бакштановкая И.В. “Нейрохимический контроль агрессии и подчинения", Jurnal Vysshej Nervnoj Dejatelnosti, vol. 41, no. 5, pp. 459-66, 1991. (In Russian: Кудрявцева Н.Н., Бакштановкая И.В. “Нейрохимический контроль агрессии и подчинения”, Журн. высш. нерв. деятельности. 41 (5): $459-466$. 1991).

[68] G. V. Idova, "Influence of the submisive and aggressive behaviours on changes in the number of T-lymphocytes CD4 + and CD8 + in the bone marrow," Immunologija, iss. 1, pp. 24-26, 2000. (In Russian: Идова Г.В., "Влияние субмисивного и агрессивного типов поведения на изменение числа Т-лимфоцитов CD4+ и CD8+ в костном мозге”, Иммунология. №1, с. 24-26, 2000).

[69] V. Stefanski, G. F. Solomon, A. S. Kling, J. Thomas, and S. Plaeger, "Impact of social confrontation on rat CD4 T cells bearing different CD45R isoforms," Brain Behav. Immunit., vol. 10, iss. 4, pp. 364-379, 1996.

[70] Y.-H. Sung, M.-S. Shin, S. Cho, H.-H. Baik, B.-K. Jin, H.-K. Chang, E.-K. Lee, and C.-J. Kim, "Depression-like state in maternal rats induced by repeated separation of pups is accompanied by a decrease of cell proliferation and an increase of apoptosis in the hippocampus," Neuroscience Letters, vol. 470, iss. 1, pp. 86-90, 2011.

[71] D. C. Blanchard, R. R. Sakai, B. McEwen, S. M. Weiss, and R. J. Blanchard, "Subordination stress: behavioral, brain, and neuroendocrine correlates," Behav. Brain. Res., vol. 58, iss. 1-2, pp. 113-121, 1993.

[72] L. V. Devojno and R. Yu. Ilyuchenok, Neurotransmitter systems in psycho-neural modulation: dopamine, serotonin, GABA, neuropeptides, Novosibirsk, 1993. (In Russian: Девойно Л.В., Ильюченок Р.Ю. Нейромедиаторные системы в психонейромодуляиии: допамин, серотонин, ГАМК, нейропепдиды. ЦЭРИС. Новосибирск. 1993. 240 с).

[73] N. N. Kudryavtseva, I. V. Bakshtanovskaya, and L. A. Koryakina, "Social model of depression in mice of C57BL/6J strain," Pharmacol. Biochem. Behav., vol. 38, iss. 2, pp. 315-320, 1991.

[74] M. V. Tenditnik, A. V. Shurlygina, E. V. Melnikova, N. N. Kudrjavtseva, and V. A. Trufakin, "Change in lymphocyte subpopulations of immunocompetent mice under the influence of chronic social stress," Rossijskij Fiziologicheskij Zhurnal imeni Sechenova, vol. 12, pp. 1522-1529, 2004. (In Russian: Тендитник М.В., Шурлыгина А.В., Мельникова Е.В., Кудрявцева Н.Н., Труфакин В.А. "Изменение субпопуляционного состава лимфоцитов иммунокомпетентных органов мышей под влиянием хронического социального стресса", Российский Физиологический Журнал имени. И.М. Сеченова. 2004. (12): 1522-1529).

[75] A. Azpiroz, A. Arregui, E. Fano, L. Garmendia, and J. R. Sánchez-Martin, "Fighting experiences and natural killer cell activity in male laboratory mice," Aggress. Behav., vol. 20, iss. 1, pp. 67-71, 1994.

[76] J. M. Dabbs Jr. and R. Morris, "Testosterone, Social Class, and Antisocial Behavior in a Sample of 4,462 Men," Psychological Science, vol. 1, pp. 209-211, 1990.

[77] E. Monagham and S. Clickman, "Hormones and aggressive behaviour,” In: Behavioral endocrinology, Cambridge, Ma: MIT Press, pp. 261-287, 1992.

[78] B. B. Svare, Hormones and aggressive behaviour, N.Y., Plenum Press, 1983.

[79] T. C. Pellegrino and B. M. Bayer, "Role of central 5-HT(2) receptors in fluoxetine-induced decreases in T lymphocyte activity," Brain Behav. Immun., vol. 16, iss. 2, pp. 87-103, 2002.

[80] A. Roman, J. Vetulani, and I. Nalepa, "Effect of combined treatment with paroxetine and transcranial magnetic stimulation (TMS) on the mitogen-induced proliferative response of rat lymphocytes," Pol. J. Pharmacol., vol. 54, iss. 6, pp. 633-639, 2002.

[81] S. Laberge, W. W. Cruikshank, D. J. Bee, and D. M. Center, "Secretion of IL-16 (lymphocyte chemoattractant factor) from serotoninstimulated CD8+ T cells in vitro," J. Immunol., vol. 156, iss. 1, pp. 310-315, 1996.

[82] E. Dotsenko, M. Bogdanova, T. Fisher, S. Petrov, and Y. Suhovey, "Synchronization of immune and psychic systems associated with social stress," Proc. CBU international conference on integration and innovation in science and education, April 7-14, Prague, Czech Republic, pp. 324-328, 2013.

[83] ojs.journals.cz/index.php/CBUConference2013/article/download/53/57.

[84] A. Ray and S. Phola, "Homeostasis and Homeorhesis: Sustaining Order and Normalcy in Human-engineered Complex Systems," 2005. [Online] Available: http://www.mne.psu.edu/ray/interdisciplinaryresearch.pdf. 